\title{
Dimensions and pattern of growth of the femoropatellar groove: A digital metric study on adult and fetal femora
}

\author{
Femoropatellar oluk boyutları ve büyüme paterni: Erişkin ve fetal femoral kemik üzerinde \\ dijital metrik bir çalışma
}

Anne D SOUZA, Vrinda Hari ANKOLEKAR, Aparna VERMA, Mamatha HOSAPATNA, Sneha Guruprasad KALTHUR

\begin{abstract}
Objectives: A detailed knowledge about the anatomy of the femoropatellar groove (FPG) and its articulation is essential for the better understanding of the patellar stability. Therefore, the present study was carried out to describe the morphology of FPG in adults and the pattern of its growth in fetuses.

Materials and Methods: Thirty-seven adult dry femora of unknown age and 24 fetal femora of known gestational age were included in the study. The dimensions of FPG and its angulations were calculated digitally using Image J software and were analyzed statistically.

Results: The femoropatellar angulation ranged from $136.38^{\circ}$ to $142.38^{\circ}$. The dimensions and angulation were correlated with the gestational age. The dimensions of FPG and the altitude of lower end of the femur increased significantly with the gestational age $(\mathrm{P}<0.05)$. There was also a significant negative correlation between the femoropatellar angulation and the gestational age $(\mathrm{P}<0.05)$.

Conclusion: This study provides a database for the parameters of the adult femora. It also describes the pattern of growth of the lower end of fetal femur. These findings are essential in determining the patellar stability during walking.
\end{abstract}

Keywords: Femoropatellar groove, Fetus, Femur, Patella, Gestational age
ÖZ

Amaç: Femoropatellar oluğun ve eklemlerinin anatomisinin detaylı bir şekilde bilinmesi, patellar stabilitenin daha iyi anlaşılmasını sağlar. Bu nedenle, bu çalışma yetişkinlerde FPG morfolojisini ve fetüslerde büyümenin paternini tanımlamak için yapılmıştır.

Gereçler ve Yöntemler: Çalışmaya, yaşları bilinmeyen 37 erişkin kuru femur ve 24 gestational yaşı bilinen fetal femur dahil edildi. Femur ve angülasyonlarının boyutları Image J yazılımı kullanılarak dijital olarak hesapland 1 ve istatistiksel olarak analiz edildi.

Bulgular: Femoropatellar angülasyon $136.38^{\circ}$ ila $142.38^{\circ}$ arasındaydı. Boyutlar ve angülasyon gebelik yaşı ile korelasyon göstermektedir. FPG'nin boyutları ve femurun alt ucunun yüksekliği, gebelik haftası ile anlamlı olarak artmıştır $(\mathrm{P}<0.05)$. Ayrıca, femoropatellar angülasyon ile gestasyonel yaş arasında anlamlı negatif korelasyon saptanmıştır $(\mathrm{P}<0.05)$.

Sonuç: $\mathrm{Bu}$ çalışma yetişkin femur parametreleri için bir veritabanı sağlar. $\mathrm{Bu}$ aynı zamanda fetal femurun alt ucunun büyüme paternini de açıklar. Bu bulgular, yürüme sırasında patellar stabiliteyi belirlemede esastır.

Anahtar kelimeler: Femoropatellar oluk, Fetus, Uyluk, Diz kapağ1, Gestasyonel yaş

\section{Introduction}

The femoropatellar joint (FPJ) is formed between the trochlea of the femur and the articular surface of the patella [1]. The morphology of the patella and trochlea is of prime importance in providing a stable and smooth platform for patellar movement along the trochlea [2]. The femoropatellar groove (FPG) or trochlear groove helps to stabilize the patella. An abnormal shallow groove predisposes to its instability [3]. It is known that femoral obliquity is not genetically determined but is attained with biped walking [4]. 
Femoropatellar (FP) articulation plays a major role in locomotion and other activities that involve knee flexion and extension. FP instability can be defined as movement of the patella out of its normal position, and can be divided into dislocation and subluxation [5]. The patella plays a major role in extensor mechanism by acting as a fulcrum [6].

The stability of the FPJ is achieved through a complex interaction of a range of factors including the articular geometry of the patella and femur, the magnitudes and lines of action of the quadriceps muscle forces, the stiffness of the retinacular structures and the relative alignment and internalexternal rotation of tibial and femoral shafts. Abnormality of any of the above factors may cause patellar malalignment within the femoral groove and leads to instability disorders such as lateral patellar compression syndrome and recurrent patellar subluxation or dislocation [7].

The stability of the patella in the trochlear groove is a combination of bony, ligamentous and muscular restraints [8]. The fundamental knowledge of anatomy of the femoropatellar articulation leads to the better understanding of patellar stability [9]. The altitudes of the femoral condyle and the FP angulation are required during the evaluation of knee joint congruence and its abnormalities [10].

Studies have also suggested that the shape of the lower extremity of the femur is determined early in development, long before standing and walking [11-13]. However, literature lacks the data of the dimensions of FPG in Indian context. Therefore, the present study was aimed to describe the morphology of FPG and the altitude of the lower end of adult and fetal femora. The study was also aimed at correlating the pattern of growth of FPG and its angulation with the gestational age using the fetal femora which would add the reference values for the existing literature.

\section{Material and Methods}

The present cross sectional study was carried out using fetal and adult femora procured from the Department of Anatomy, Kasturba Medical College, India. Thirty-seven dry adult femora of unknown age and 24 fetal femora of known gestational age were included in the study. Clearance for the study was obtained from the Institutional Ethics Committee. Damaged femora and fetuses with any limb anomaly were excluded from the study. Fetal femora were dissected and were cleared from all the soft tissues.
End on view of the lower end of the femora were taken using Nikon digital camera and were stored in JPEG format. The maximum altitudes of the right and left femoral condyles were measured at the extreme ends of the FPG. The minimum altitude of the lower end of the femur was measured at the center of the FPG. The dimensions of the FPG and the angulation were calculated digitally using Image J software and the data were stored in excel format for statistical analysis. The measured dimensions are shown in Figure 1. The same parameters were measured in both adult as well as fetal femora.

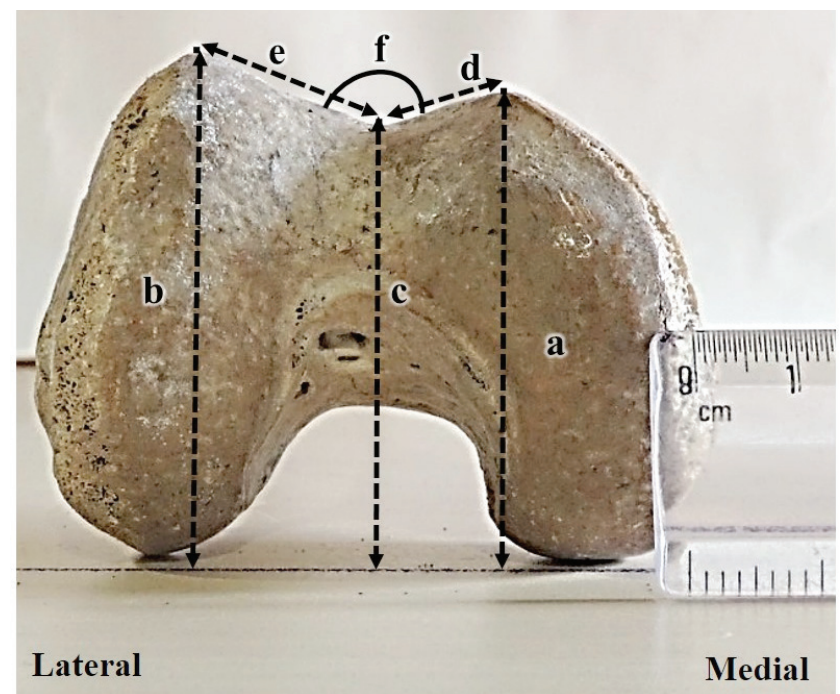

Figure 1. End on view of the lower end of right femur showing the parameters measured

a and b: Maximum altitude of the medial and lateral margins of the patellar groove

c: Minimum height of the lowest point on the patellar groove d and e: Width of the medial and lateral sides of the patellar groove f: Angle of patellar groove

Mean and standard deviations were calculated for all the parameters. All the fetal parameters were correlated with the gestational age for estimating the pattern of growth.

\section{Results}

The mean and standard deviations of the altitude of the lower end of femur and dimensions of FPG measured in adult femora are shown in Table I. The femoropatellar angulation ranged from $136.38^{\circ}$ to $142.38^{\circ}$ in adult femora. The dimensions of right and left femora were not compared statistically because they were not of the same individual.

The gestational age of the fetuses ranged from 16 to 36 weeks. The dimensions and angulation of the femoral condyles and FPG were correlated with the gestational age. 
Table I. The mean and standard deviations of the parameters measured

\begin{tabular}{lll}
\hline Parameter measured in cm & Right & Left \\
\hline Maximum altitude of the medial margin of the patellar groove & $4.98 \pm 0.35$ & $5.2 \pm 0.16$ \\
\hline Maximum altitude of the lateral margin of the patellar groove & $5.44 \pm 0.40$ & $5.50 \pm 0.14$ \\
Minimum height of the lowest point on the patellar groove & $4.89 \pm 0.21$ & $4.94 \pm 0.04$ \\
Width of the medial side of the patellar groove & $1.30 \pm 0.38$ & $1.88 \pm 0.16$ \\
Width of the lateral side of the patellar groove & $2.30 \pm 0.09$ & $1.90 \pm 0.10$ \\
\hline Angle of patellar groove & $136.38 \pm 2.59^{\circ}$ & $142.38^{\circ}$ \\
\hline
\end{tabular}

The dimensions of FPG and the altitude of lower end of the femur increased significantly with the gestational age $(\mathrm{P}<0.05)$.

In fetal femora, the mean and standard deviations of the maximum altitude of the medial femoral condyle were $1.57 \pm 0.27 \mathrm{~cm}$ and $1.53 \pm 0.288 \mathrm{~cm}$ on the right and left sides respectively. The mean and standard deviations of the maximum altitude of the lateral femoral condyle were $1.64 \pm 0.31 \mathrm{~cm}$ and $1.67 \pm 0.33 \mathrm{~cm}$ on the right and left sides respectively. The mean and standard deviations of the minimum altitude of the lower end of the femur at the center of FPG were $1.5 \pm 0.31 \mathrm{~cm}$ and $1.49 \pm 0.32 \mathrm{~cm}$ on the right and left sides respectively.

In fetuses the femoropatellar angulation ranged from $138.72^{\circ}$ to $157.75^{\circ}$. There was a significant negative correlation found between the gestational age and the femoropatellar angulation $(\mathrm{P}<0.05)$. The change in the femoropatellar angulation is depicted in Figure 2.

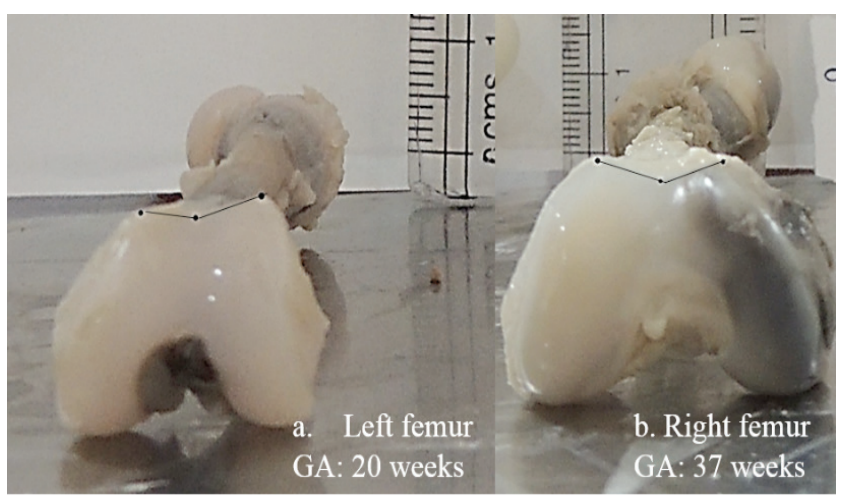

Figure 2. End on views of fetal femora indicating the change in the femoropatellar angulation

$155^{\circ}$ at $20^{\text {th }}$ week of gestation (a) and $147^{\circ}$ at 37 weeks of gestation (b) depicted in black line.

GA: Gestational age

\section{Discussion}

The literature mentions several studies concerning the FPG and femoropatellar pathology in children and in adults.

Doskocil in 1985 published the first series concerning the anatomy of the FPG in embryos of 4 to 10 weeks of gestational age. He stated that, the patellar groove was asymmetric, with a lateral lip bigger and wider than the medial one, but it was a subjective and visual observation, without any biometry or measurement [11]. Similar observations were noted in the present study.

Doskocil also pointed out that during development there is a distal migration of the patella to its final place, and this occurs within the third month of intrauterine life. This variation modifies the position of the patella in its femoral groove and could be responsible for mechanical remodeling of joint surfaces [11].

Biometric evaluation series of the patellar groove in adults was carried out by Wanner et al., which comprised 32 right femurs from the Colorado University. He pointed out that the lateral side of the FPG was more elevated than the medial one, and that the lateral side of the FPG was about twice as wide as the medial one. He also showed that these parameters were very variable, but the angulation had a remarkable stability [14]. An asymmetric patellar groove with a lateral side that sticks out, associated with an oblique femur, is a specific mark of biped walk for many authors [15, 16]. In the current study, there was a significant difference in the parameters of the medial and lateral margins of the FPG which were in agreement with Wanner's observations.

Nietosvaara carried out an ultrasonographic study on knees of 50 normal children aged from birth to 18 years to measure the angles of the bony intercondylar and the cartilaginous FPG. At all ages, the angle of the cartilaginous groove was 134 to 155 degrees, although the osseous angle was found to be inversely related to the child's age. The authors suggested that the configuration of the FPG is 
already well developed at birth [17]. In the current study, the mean FP angulation observed was $138.72^{\circ}$ to $157.75^{\circ}$ on the right and left sides respectively in fetal femora. It was also observed that the femoropatellar angulation was inversely proportional to the gestational age.

Many clinical investigators have related the radiological appearances of the femoropatellar joint to femoropatellar pain, malalignment, chondromalacia of the patella, abnormal femoropatellar angulation, congruence, patellar subluxation and dislocation, dysplasia of the patella and of the femoral trochlea, patellar position and movement [18-21].

A study done by Glard et al., on fetuses of 13 to 38 weeks of gestation showed a positive correlation between the FP angulation and the dimensions of the lower end of the femur [4]. However, in the current study the authors observed a significant positive correlation for the parameters of lower end of femur and a negative correlation for the FP angulation.

\section{Conclusion}

This study provides a range of dimensions of the lower end of femur and the femoropatellar angulation which would be added to the existing database. The study also provides the pattern of growth of lower end of fetal femur. These findings are essential in determining the patellar stability during walking. The altitudes of the femoral condyles and the angulation are also required during the evaluation of knee joint congruence and its abnormalities.

\section{Funding: NIL}

Conflict of interest: None to declare

\section{References}

1. Nickel R, Schummer A, Seiferle E, Wilkens, Wille KH, Frewein J. The locomotor system of the domestic mammals. The anatomy of domestic animals. Berlin. Hamburg: Verlag Paul Parey, 1986.

2. Dwek JR, Chung CB. The patellar extensor apparatus of the knee. Pediatr Radiol 2008;38:925-35. doi: 10.1007/s00247008-0746-8.

3. Willam P, Lawrence HB, Martin MB. Gray's Anatomy. 38th edn. London: Churchill Livingstone, 1995.

4. Glard Y, Jouve JC, Panuel M, Adalian P, Tardieu C, Bollini G. An anatomical and biometrical study of the femoral trochlear groove in the human fetus. J Anat 2005;206:411-3. doi:10.1002//pd.1024.

5. Schindler OS, Scott WN. Basic kinematics and biomechanics of the patello-femoral joint. Part 1: The native patella. Acta Orthop Belg 2011;77:421-31. doi: 10.1007/s00167-0132825-0

6. Sutton FS Jr, Thompson CH, Lipke J, Kettelkamp DB. The effect of patellectomy onknee function. J Bone Joint Surg Am 1976;58:537-40. doi:10.1242/dev.121970

7. Fox JM, Del Pizzo W. The patellofemoral joint, 2nd edition. New York: McGraw-Hill, 1993.

8. Goldblatt J, Richmond J. Anatomy and biomechanics of the knee. Operative technique in sports medicine. 2003;11:17286. doi: 10.1097/JSA.0b013e318053eb74

9. Galland O, Walch G, Dejour H, Carre J. An anatomical and radiological study of the femoropatellar articulation. Surg Radiol Anat 1990;12:119-25. doi.org/10.1078/0949328X-00108

10. Stäubli HU, Dürrenmatt U, Porcellini B, Rauschning W. Anatomy and surface geometry of the patellofemoral joint in the axial plane. J Bone Joint Surg [Br] 1999;81-B:452-8. doi 0301-620X/99/38758

11. Doskocil M. Formation of the femoropatellar part of the human knee joint. Folia Morphol 1985;33:38-47. doi:10.1111/j.1469-7580.2005.00400

12. Gray D, Gardner E. Prenatal development of the human knee and superior tibiofibular joints. Am J Anat 1950;86:233-87. doi.org/10.1002/aja.1000860204

13. Walmsley T. The development of the patella. J Anat 1940;74:360-8.

14. Wanner JA. Variations in the anterior patellar groove of the human femur. Am J Phys Anthropol 1977;47:99-102. doi: 10.1111/j.1469-7580.2005.00400.x

15. Heiple KJ, Lovejoy CO. The distal femoral anatomy of Australopithecus. Am J Phys Anthrop 1971;35:75-84. doi. org/10.1002/ajpa.1330350109

16. Tardieu C, Trinkaus E. Early ontogeny of the human femoral bicondylarangle. Am J Phys Anthrop 1994;95:183-95. doi:10.1002/ajpa.1330950206

17. Nietosvaara Y. The femoral sulcus in children. An ultrasonographic study. J Bone Joint Surg 1994;76:807-9. doi: 10.1302/0301-620X.76B5.8083274

18. Aglietti $P$, Insall JN, Cerulli G. Patellar pain and incongruence: measurements of incongruence. Clin Orthop 1983;176:21724.

19. Schutzer F, Ramsby GR, Fulkerson JP. The evaluation of patellofemoral pain using computerized tomography: a preliminary study. Clin Orthop 1986;204:286-93.

20. Sasaki T, Yagi T. Subluxation of the patella: investigation by computerized tomography. Int Orthop 1986;10:115-20. doi:10.1007/BF00267752

21. Hughston JC. Subluxation of the patella. J Bone Joint Surg 1968;50-A:1003-26. doi: 10.1007/BF00267752 